\title{
ANALISA TINGKAT PENGETAHUAN DAN PERILAKU TERHADAP PENGGUNAAN OBAT INFLUENZA DAN BATUK SECARA SWAMEDIKASI DI DESA MUARA BURNAI I KABUPATEN OGAN KOMERING ILIR
}

\section{An Analysis Of The Level Of Knowledge And Behavior Towards The Use Of Influenza Medicine And Cough Swamedication In Muara Burnai I Village Ogan Komering Ilir District}

\author{
Mashuri Yusuf ${ }^{1}$, Subur Widodo ${ }^{2}$, Aqbar Raka Irwansyah ${ }^{3}$ \\ Fakultas MIPA, Jurusan Farmasi Universitas Tulang Bawang Lampung \\ Email : mashuriyusuf09@gmail.com
}

\begin{abstract}
Abtract
Many Indonesian people do self-medication as an attempt to treat complaints / pain they experience, the benefit of self-medication is safe when used according to the rules, effective for eliminating complaints, cost efficiency, can play a role in making therapeutic decisions, self-medication is usually done to overcome complaints and minor illnesses that are often experienced by people, such as fever, pain, dizziness, cough, influenza, ulcers, intestinal worms, diarrhea, skin diseases and others. This study aims to determine the level of knowedge and behavior towards the use of influenza drugs and cough by self-medication in Muara Burnai I Village, Ogan Komering llir district. The research analyzed was descriptive observational. The sampling technique uses the accindental sampling method. The instrument used in this study was a questionnaire. The results of the analysis of the level of knowedge and behavior analysis showed that there was a relationship between the level of knowedge and the behavior of influenza drug use and cough by self-medication was analyzed using the Chi-Square test sample of 100 respondents. The results of this study indicate that 36\% have high knowedge and $64 \%$ have low knowledge in self-influencing and cough swamedication while $43 \%$ have high behavior and $57 \%$ have low behavior in influenza and cough swamedication in Muara Burnai I Village, Ogan Komering llir District. Based on the Chi-Square test results showed that the value of $p=0,000(0.05)$. Shows that there is a relationship between the level of knowedge and swamedication behavior in Muara Burnai I Village, Ogan Komering Ilir district.
\end{abstract}

Keywords : Influenza and cough, drug use behavior, swamedication, knowedge level.

\section{Abstrak}

Masyarakat Indonesia banyak yang melakukan swamedikasi sebagai usaha untuk merawat keluhan/sakit yang dialaminya, keuntungan swamedikasi yaitu aman bila digunakan sesuai dengan aturan, efektif untuk menghilangkan keluhan, efisiensi biaya, bisa ikut berperan dalam mengambil keputusan terapi, swamedikasi biasanya dilakukan 
untuk mengatasi keluhan-keluhan dan penyakit ringan yang sering dialami masyarakat, seperti demam, nyeri, pusing, batuk, influenza, sakit mag, cacingan, diare, penyakit kulit dan lain lain. Penelitian ini bertujuan ntuk mengetahui tingkat pengetahuan dan perilaku terhadap penggunaan obat influenza dan batuk secara swamedikasi di Desa Muara Burnai I Kabupaten Ogan Komering llir . Penelitian yang dianalisis secara observasional deskriptif. Teknik pengambilan sampel menggunakan metode accindental sampling. Instrumen yang digunakan dalam penelitian ini adalah kuesioner. Hasil penelitian analisa tingkat pengetahuan dan perilaku menunjukan bahwa ada hubungan antara tingkat pengetahuan dengan perilaku penggunaan obat influenza dan batuk secara swamedikasi dianalisis menggunakan uji Chi-Square sampel sebanyak 100 responden. Hasil penelitian ini menunjukan bahwa 36\% berpengetahuan tinggi dan $64 \%$ berpengetahuan rendah dalam melakukan swamedikasi influenza dan batuk sedangkan $43 \%$ berperilaku tinggi dan $57 \%$ berperilaku rendah dalam melakukan swamedikasi influenza dan batuk di Desa Muara Burnai I Kabupaten Ogan Komering llir. Berdasarkan hasil uji Chi-Square menunjukan bahwa nilai $p=0,000(0,05)$. Menunjukan bahwa adanya hubungan antara tingkat pengetahuan dan perilaku swamedikasi di Desa Muara Burnai I Kabupaten Ogan Komering llir.

Kata kunci : Inluenza dan batuk, perilaku penggunaan obat, swamedikasi, tingkat pengetahuan.

\section{PENDAHULUAN}

Kesehatan adalah keadaan sehat, baik secara fisik, mental, spiritual maupun sosial yang memungkinkan setiap orang untuk hidup produktif secara sosial dan ekonomis, kesehatan merupakan hak asasi manusia dan salah satu unsur kesejahteraan yang harus diwujudkan sesuai dengan cita-cita bangsa indonesia sebagaimana dimaksud dalam Pancasila dan Undang-undang Dasar Negara Republik Indonesia tahun 1945 [1].

Swamedikasi adalah pengobatan tanpa supervisi, karena itu swamedikasi bukanlah cara pengobatan yang sepenuhnya aman. Resiko potensial akibat praktik swamedikasi antara lain adalah salah diagnosis, penundaan pencarian konsultasi medis saat dibutuhkan, terjadinya efek samping berat walaupun jarang, terjadinya interaksi obat yang berbahaya, salah dalam mengkonsumsi obat, salah dosis, salah pilihan terapi dan munculnya resiko ketergantungan dan penyalahgunaan obat namun, untuk obat-obat golongan bebas dan bebas terbatas, termasuk golongan obat yang relatif aman digunakan dalam swamedikasi [2].

\section{Berdasarkan PERMENKES} NO919/MENKES/PER/X/1993

1. Tidak dikontraindikasikan untuk penggunaan pada wanita hamil, anak dibawah usia 2 tahun dan orang tua di atas 65 tahun.

2. Tidak memberikan resiko pada kelanjutan penyakit.

3. Tidak memerlukan cara atau alat khusus .

4. Untuk penyakit yang prevalensinya tinggi di indonesia.

5. Rasio khasiat keamanan obat dapat dipertanggungjawabkan [3].

Menurut World Health Organization (WHO) swamedikasi diartikan sebagai pemilihan dan penggunaan obat, termasuk pengobatan herbal dan tradisional, oleh individu untuk merawat diri sendiri dari penyakit atau gejala penyakit. Swamedikasi biasanya dilakukan untuk mengatasi keluhankeluhan dan penyakit ringan yang sering dialami masyarakat, seperti demam, nyeri, pusing, batuk, influenza, sakit mag, kecacingan, diare, penyakit kulit dan lain-lain. Obat-obat golongan obat 
bebas dan obat bebas terbatas merupakan obat yang relatif aman digunakan untuk swamedikasi, swamedikasi adalah upaya awal yang dilakukan sendiri dalam mengurangi/mengobati penyakit-penyakit ringan menggunakan obat-obatan dari golongan obat bebas dan bebas terbatas [4].

Swamedikasi harus dilakukan sesuai dengan penyakit yang dialami. Pelaksanaannya harus memenuhi kriteria penggunaan obat yang rasional, antara lain ketepatan pemilihan obat, ketepatan dosis obat,tidak adanya efek samping, kontraindikasi, interaksi obat, dan tidak adanya polifarmasi [5].

Pada penelitian sebelumnya yang dilakukan di surabaya di desa Gubeng Airlangga, sebagian besar masyarakat memiliki pengetahuan yang tinggi (45\%) dalam memilih dan menggunakan obat batuk secara swamedikasi. Namun pada beberapa variabel pengetahuan terkait obat influenza dan batuk masih banyak yang tergolong buruk, seperti dalam pemilihan obat influenza dan batuk atau tepat indikasi sebesar 56 orang, dosis sekali pakai sebesar 59 orang, dan tanggal kadaluwarsa sebesar 54 orang. Hasil penelitian menunjukkan bahwa masih kurangnya pengetahuan masyarakat terkait penggunaan obat influenza dan batuk secara swamedikasi [6].

Berdasarkan latar belakang diatas peneliti memilih Desa Muara Burnai I, Kecamatan lempuing Jaya, Kabupaten Ogan Komering llir, Sumatera Selatan . Desa ini jaraknya lumayan jauh dari pusat perkotaan dengan mayoritas penduduk berasal dari kalangan menengah kebawah, ketika sakit kebanyakan masyarakat nya melakukan swamedikasi untuk mengobati penyakit yang di alami, sarana dan prasarana kesehatan di desa ini masih minim hal ini dikarenakan hanya terdapat 2 bidan desa pembantu dan tidak terdapatnya apotek dan belum pernah belum pernah ada penelitian sejenis di desa Muara
Burnai I sehingga peneliti tertarik untuk menjadikan subjek penelitian

\section{METODE PENELITIAN}

\section{Waktu dan Tempat Penelitian}

Penelitian ini dilakukan pada bulan April tahun 2020 dilakukan di Desa Muara Burnai I Kabupaten Ogan Komering llir

\section{Jenis Penelitian}

Penelitian ini merupakan penelitian deskriptif observasional dengan metode pengambilan data secara accidental sampling yang didasarkan pada data masyarakat Desa Muara Burnai I Kabupaten Ogan Komering lir

\section{Populasi dan Sampel Penelitian Populasi}

Populasi penelitian ialah masyarakat Desa Muara Burnai I Kabupaten Ogan Komering llir. Sampel penelitian ialah sebagian masyarakat pasien di Desa Muara Burnai I Kabupaten Ogan Komering llir yang Berumur 18-60 tahun Penentuan sampel menggunakan rumus slovin [7].

$$
\mathrm{n}=\frac{\mathrm{N}}{1+\mathrm{N}(\mathrm{d})^{2}}
$$

$$
\begin{aligned}
& \text { jadi , } \\
& \mathrm{n}=\frac{7.300}{1+7.300(0,1)^{2}} \\
& \mathrm{n}=\frac{7.300}{74} \\
& \mathrm{n}=98,64 \\
& \mathrm{n}=100 \text { sampel }
\end{aligned}
$$

\section{Dimana}

$\mathrm{n}=$ jumlah sampel

$\mathrm{N}=$ jumlah populasi

$\mathrm{d}=$ batas toleransi kesalahan pengambilan sampel

jadi, sampel terpilih dengan menggunakan rumus diatas yaitu sebanyak 100 Responden 


\section{Analisis Data}

1. Karakteristik Responden

Karakteristik responden meliputi jenis kelamin, usia, pendidikan, dan pekerjaan. Karakterisrik responden digunakan untuk menganalisa jawaban kuisioner pada setiap responden

2. Penilaian Kuesioner

Jawaban dari kuisioner dianalisis dengan melakukan skoring pada kuisoner yang diberikan kepada responden dengan menggunakan skala Guttman.

3. Tingkat Kesesuaian

Tingkat pengetahuan dikatakan rendah yaitu nilai kurang $50 \%$ sedangkan tingkat pengetahuan dikatakan tinggi nilai diatas $50 \%$. Pada penelitian menggunakan skala Guttman yang dibuat dalam pilihan ganda yaitu " benar dan salah. Untuk mengetahui posisi persentase jawaban yang diperoleh maka akan dihitung dalam rentan skala persentasi sebagai berikut :

Nilai jawaban benar : 1

Nilai jawaban salah : 0

Dikonvesikan dalam persentase: Jawaban Benar : $1 \times 100 \%=1$ Jawaban Salah : $0 \times 100 \%=0$

\section{HASIL DAN PEMBAHASAN}

Tabel 1. Hubungan antara tingkat pengetahuan dan perilaku swamedikasi di Desa Muara Burnai I Kabupaten Ogan Komering llir.

\begin{tabular}{|c|c|c|c|c|c|c|c|}
\hline \multirow{3}{*}{$\begin{array}{c}\text { Pengetah } \\
\text { uan }\end{array}$} & \multicolumn{4}{|c|}{ Perilaku } & \multirow{2}{*}{\multicolumn{2}{|c|}{ Total }} & \multirow{3}{*}{$\begin{array}{c}P \\
\text { val } \\
\text { ue }\end{array}$} \\
\hline & \multicolumn{2}{|c|}{$\begin{array}{c}\text { Ting } \\
\text { gi }\end{array}$} & \multicolumn{2}{|c|}{$\begin{array}{c}\text { Rend } \\
\text { ah }\end{array}$} & & & \\
\hline & & $\%$ & $N$ & $\%$ & $\mathrm{~N}$ & $\%$ & \\
\hline Tinggi & 6 & $\begin{array}{l}3 \\
6 \\
\%\end{array}$ & 0 & $0 \%$ & $\begin{array}{l}3 \\
6\end{array}$ & $\begin{array}{l}3 \\
6 \\
\%\end{array}$ & $\begin{array}{l}0,0 \\
00\end{array}$ \\
\hline Rendah & 7 & $\begin{array}{l}7 \\
\%\end{array}$ & $\begin{array}{l}5 \\
7\end{array}$ & $\begin{array}{l}57 \\
\%\end{array}$ & $\begin{array}{l}6 \\
4\end{array}$ & $\begin{array}{l}6 \\
4 \\
\%\end{array}$ & \\
\hline
\end{tabular}

Pada hasil uji Chi Square hubungan tingkat pengetahuan dan perilaku swamedikasi $P 0.000(p<0.05)$ sehingga Ho di tolak dan $\mathrm{H} 1$ diterima. Hasil uji tersebut diperoleh bahwa ada hubungan antara tingkat pengetahuan dan perilaku penggunaan obat secara swamedikasi.

Tabel 2. Hubungan Antara Jenis Kelamin Dengan Tingkat Pengetahuan Dan Perilaku Obat Secara Swamedikasi

\begin{tabular}{|l|l|}
\hline $\begin{array}{l}\text { Hubungan antara jenis } \\
\text { kelamin dengan Tingkat } \\
\text { pengetahuan dan } \\
\text { penggunaan obat }\end{array}$ & P value \\
\hline Pengetahuan & 0.615 \\
\hline Perilaku & 0.503 \\
\hline
\end{tabular}

Pada hasil uji Chi Square tingkat pengetahuan di peroleh nilai $P 0.615$ dan perilaku $P 0.503(p<0.05)$ sehingga $\mathrm{Ho}$ di terima dan $\mathrm{H} 1$ di tolak. Hasil uji tersebut diperoleh bahwa tidak ada hubungan antara jenis kelamin terhadap tingkat pengetahuan dan penggunaan obat secara swamedikasi.

Tabel 3. Hubungan antara Usia dengan tingkat pengetahuan dan perilaku penggunaan obat secara swamedikasi

\begin{tabular}{|l|l|}
\hline $\begin{array}{l}\text { Hubungan antara Usia } \\
\text { dengan Tingkat pengetahuan } \\
\text { dan Perilaku penggunaan } \\
\text { obat }\end{array}$ & P value \\
\hline pengetahuan & 0.011 \\
\hline Perilaku & 0.083 \\
\hline
\end{tabular}

Pada hasil uji Chi Square tingkat pengetahuan di peroleh nilai $P 0.011$ dan perilaku $P 0.083(p<0.05)$ sehingga $\mathrm{Ho}$ di terima dan $\mathrm{H} 1$ di tolak . Hasil uji tersebut di peroleh bahwa tidak ada hubungan antara Usia terhadap tingkat pengetahuan dan perilaku penggunaan obat secara swamedikasi. 
Tabel 4. Hubungan antara pendidikan terakhir dengan tingkat pengetahuan dan perilaku penggunaan obat secara swamedikasi.

\begin{tabular}{|l|c|}
\hline $\begin{array}{l}\text { Hubungan antara pendidikan } \\
\text { dengan Tingkat pengetahuan } \\
\text { Dan perilaku penggunaan obat }\end{array}$ & $\mathrm{P}$ value \\
\hline pengetahuan & 0.000 \\
\hline Perilaku & 0.000 \\
\hline
\end{tabular}

Pada hasil uji Chi Square tingkat pengetahuan di peroleh nilai $P 0.000$ dan penggunaan obat $P \quad 0.000 \quad(p<0.05)$ sehingga $\mathrm{Ho}$ di tolak dan $\mathrm{H} 1$ di teriama . Hasil uji tersebut di peroleh bahwa ada hubungan antara pendidikan terhadap tingkat pengetahuan dan perilaku penggunaan obat secara swamedikasi.

Tabel 5. Hubungan antara pekerjaan dengan tingkat pengetahuan dan perilaku penggunaan obat secara swamedikasi.

\begin{tabular}{|l|l|}
\hline $\begin{array}{l}\text { Hubungan antara Pekerjaan } \\
\text { dengan Tingkat pengetahuan } \\
\text { dan perilaku penggunaan } \\
\text { obat }\end{array}$ & P value \\
\hline pengetahuan & 0.000 \\
\hline Perilaku & 0.000 \\
\hline
\end{tabular}

Pada hasil uji Chi Square tingkat pengetahuan di peroleh nilai $P 0.000$ dan penggunaan obat $P \quad 0.000 \quad(p<0.05)$ sehingga $\mathrm{Ho}$ di tolak dan $\mathrm{H} 1$ di terima . Hasil uji tersebut di peroleh bahwa ada hubungan antara pekerjaan terhadap tingkat pengetahuan dan perilaku penggunaan obat secara swamedikasi
Tabel 6. Hubungan antara penghasilan dengan tingkat pengetahuan dan perilaku penggunaan obat secara swamedikasi

\begin{tabular}{|l|l|}
\hline $\begin{array}{l}\text { Hubungan antara } \\
\text { penghasilan dengan Tingkat } \\
\text { pengetahuan } \\
\text { Dan perilaku penggunaan } \\
\text { obat }\end{array}$ & $\mathrm{P}$ value \\
\hline \multicolumn{1}{|c|}{ pengetahuan } & 0.000 \\
\hline Perilaku & 0.000 \\
\hline
\end{tabular}

Pada hasil uji Chi Square tingkat pengetahuan di peroleh nilai $P 0.000$ dan penggunaan obat $P \quad 0.000 \quad(p<0.05)$ sehingga $\mathrm{Ho}$ di tolak dan $\mathrm{H} 1$ di terima . Hasil uji tersebut di peroleh bahwa ada hubungan antara pendidikan terhadap tingkat pengetahuan dan perilaku penggunaan obat secara swamedikasi

\section{SIMPULAN DAN SARAN}

\section{Kesimpulan}

Berdasarkan penelitian maka dapat disimpulkan:

1. Ada hubungan antara tingkat pengetahuan dan perilaku, usia dengan tingkat pengetahuan, pendidikan dengan tingkat pengetahuan, pendidikan dengan perilaku, pekerjaan dengan tingkat pengetahuan, pekerjaan dengan perilaku penghasilan dengan tingkat pengetahuan, penghasilan dengan perilaku dan tidak adanya hubungan antara jenis kelamin dengan tingkat pengetahuan, jenis kelamin dengan perilaku, usia dengan perilaku.

2. Terdapatnya responden yang berpengetahuan tinggi sebesar 36 responden $(36 \%)$ dan responden yang berpengetahuan rendah sebesar 64 responden (64\%).

3. Terdapatnya responden yang berperilaku tinggi sebesar 43 responden $(43 \%)$ dan responden yang berperilaku rendah sebesar 57 responden (57\%). 
Saran

1. Bagi responden

Diharapkan responden dalam melakukan swamedikasi obat influenza dan batuk sebaiknya dikonsultasikan terlebih dahulu kepada tenaga farmasi atau apoteker dan tenaga kesehatan lainnya.

2. Bagi peneliti selanjutnya

Diharapkan penelitian lebih lanjut dengan desain dan variabel yang berbeda dan perlu dilakukan dengan jumlah sampel yang lebih besar untuk mengetahui hubungan seluruh faktor yang berhubungan dengan tingkat pengetahuan dan perilaku penggunaan obat influenza dan batuk.

\section{DAFTAR PUSTAKA}

[1] Presiden,DPR, Undang-Undang Republik Indonesia Nomor 36 Tahun 2009 Tentang Kesehatan

[2] Simanjuntak NH.2017 Perilaku Pengobatan Medan Tahun 2017 Sendiri Masyarakat Kota.

[3] Weni W,Lily RG,Ni Wayan EM,2013 Dampak Penyuluhan Pada Pengetahuan Masyarakat Terhadap Pemilihan dan Penggunaan Obat Batuk Swamedikasi Di Kecamatan Malayang.Jurnal IImiah Farmasi 2(3); Hal 4

[4] World Health Organization.2014.The Role of the Pharmacist in Self-Care and Self-Medication Contents

[5] Nopitasari BL,Qiyaam N, 2018 Buku Ajar Diploma III Farmasi Swamedikasi. Yogyakarta; CV Budi Utama. Hal 21- 24.

[6] Khuluqiyah, I, Nurrahmah, N, Nourah, S, Fauziah, F, Shana, N,
Aquila, F 2016 Tingkat pengetahuan masyarakat mengenai penggunaan obat batuk secara swamedikasi. Jurnal Farmasi Komunitas 3(2); Hal 4

[7] Notoadmojo S. 2010. Metodelogi Penelitian Kesehatan. Jakarta; Widya Medik 
JFL

Jurnal Farmasi Lampung

Vol. 9 No.2, Desember 2020 